Journal of Engineering and Applied Sciences 14 (12): 4285-4289, 2019

ISSN: $1816-949 \mathrm{X}$

(C) Medwell Journals, 2019

\title{
Geophysical Investigation of Aquifer Layer of Landmark University Community, Omu-Aran, Nigeria using Electrical Resistivity Method
}

\author{
Odeyemi Emmanuel Oloruntoba, Daodu Oluwafemi and A. Olaonipekun Oluwasegun \\ Department of Physical Planning and Development, Landmark University, \\ Omu-Aran Km 4 Ipetu Road, P.M.B., 1001 Omu-Aran, Nigeria
}

\begin{abstract}
The availability of water is one challenge confronting Landmark University community an institution on the outskirt of Omu-Aran, Southwestern Nigeria. Geophysical survey was carried out to evaluate the ground water potential of the basement complex and to delineate potential locations for siting boreholes within the community. A total of seven Vertical Electrical Sounding (VES) were carried out. Data acquisition involved the use of shlumberger electrode configuration with half current electrode spacing $(\mathrm{AB} / 2)$ ranging from $1-100 \mathrm{~m}$. Interpretation of the geoelectric data involved the use of curve matching technique and computer iteration. Available lithologic data from previous workers were used to evaluate geophysical results. The interpretation revealed three and four model curves, $\mathrm{H}, \mathrm{HA}, \mathrm{A}$ and $\mathrm{KH}$-types with the $\mathrm{KH}$-type curves being the dominant types. Four subsurface layers comprising top soil, lateritic soil, weathered layer, fractured basement and fresh basement were inferred from the interpretation. The top/lateritic soil layers are of varying thickness and resistivity values. The fractured and weathered basements with relatively lower resistivity are inferred to be aquiferous zone and could bear productive water for ground water supply. The basement has the lower most infinitely thick layer with resistivity mostly $<1500 \mathrm{dm}$. The results of the soundings greatly contribute to the understanding of the hydro geology of the basement complex. The fractured and weathered basement aquifers can be developed for suitable water supply to the university community.
\end{abstract}

Key words: Vertical electrical sounding, groundwater, basement, Landmark University, weathered basement, infinitely

\section{INTRODUCTION}

Mapping of geologic structures such as geological boundaries, fractures and faults are successfully accomplished using the applications of potential field geophysical prospecting methods. These geophysical methods have been useful in a diversity of ways to provide helpful information about the subsurface basement geological structures that may reflect the greater potential for the occurrence of aquifer in a particular area.

Potential-field geophysical prospecting methods have been shown to provide information within which subsurface structural geological features emerge. These techniques do not deal only with the applications of the methods to explore valuable and precious subsurface materials but also find significance in the oil and gas prospecting (Abedi ad. $_{\text {, }}$ 2013).

Many workers have previously reported published work on the Nigerian precambrian basement complex using a range of approaches (Obaje, 2009; Rahaman, 1988;
Woakes at., 1987; Oyinloye, 1998; Olasehinde as., 1990; Olade and Elueze, 1979 and Scheidegger and Ajakaiye, 1985).

This present study is aimed to delineate the basement structures (fracture) that favour quantitative to map out basement structures that have potential for water prospects using electrical resistivity method of geophysical prospecting.

\section{MATERIALS AND METHODS}

The study area lies within the Southwestern schist belt and surrounded by Longitudes $8^{\circ} 12^{\prime} 14.08^{\prime \prime} \mathrm{E}$ and $5^{\circ}$ $5^{\prime} 23.76^{\prime \prime}$ E and Latitudes 7R 59' $45.6^{\prime \prime} \mathrm{N}$ and $8^{\circ} 30^{\prime} 22.21^{\prime \prime}$ $\mathrm{N}$ (Fig. 1). The South-Western part of the Nigerian schist belts are well-developed in the country alongside the Western border of the study area at Longitudes $4-8^{\circ} \mathrm{E}$ and latitudes $6-10^{\circ} \mathrm{N}$. Insignificant amounts of schist formations were recognised in the eastern area, although, occasionally. As shown in Fig. 1, the Nigerian schist belts are confined to NNE-trending zones across a width of

Corresponding Author: Odeyemi Emmanuel Oloruntoba, Dapartment of Physical Planning and Development, Landmark University, Omu-Aran Km 4 Ipetu Road, P.M.B., 1001 Omu-Aran, Nigeria 


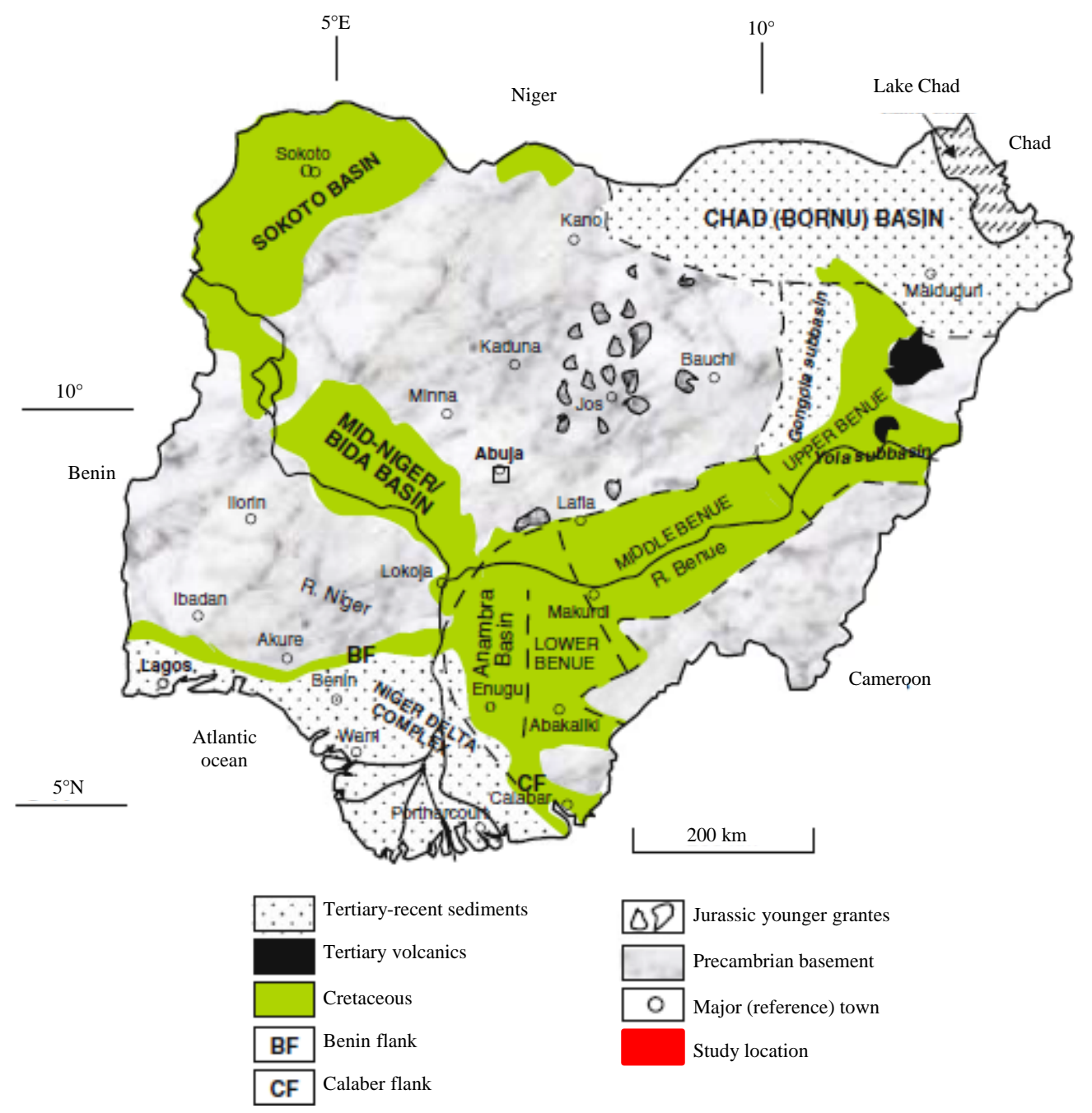

Fig. 1: Geological sketch map of Nigeria showing the study location

about 300 km (Ako, 1980; Ajayi, 1981; Annor as., 1997; Obaje, 2009). Gneisses and migmatites that constitute the dahomeyan units made up some of the region to the West of this geographical area. Likewise, to the East of the Nigerian South-Western schist belt, spanning a region up to about $700 \mathrm{~km}$ wide there is no known existence of schist rocks with the exception of cameroun where varieties of these types of rocks thought to be of the upper proterozoic age, crop out within the Pan-African granite migmatite terrain sited in the Northern part of the congo craton (Obaje, 2009; Rahaman, 1988; Woakes as., 1987).

The survey was carried out using ABEM WADI instrument with other accessories such as hand-held Global Positioning System (GPS) and measuring tape. A total of 7 profile stations were conducted within the university community with profile length ranging from
$100 \mathrm{~m}$. Readings were taken at station interval of $5 \mathrm{~m}$ in the 3 locations with profile lines oriented in N-S, E-W directions, respectively. The profiles were denoted as VES 01-07.

\section{RESULTS AND DISCUSSION}

Data interpretation: The apparent resistivity data obtained from the field was plotted against half of the current electrode spacing $(\mathrm{AB} / 2)$ on a $\log -\log$ scale. The data was fistt interpreted usisng conventional partial curve maching and drawing of auxiliary point diagram, results served as input for computer iteration procedure. The prime motive of the VES interpretation method is the determaination of the number of layers, thickness of layer in meters and resistivity of layers in $\mathrm{m}$. the interpretation of the curve was based on the principle that 
(a)

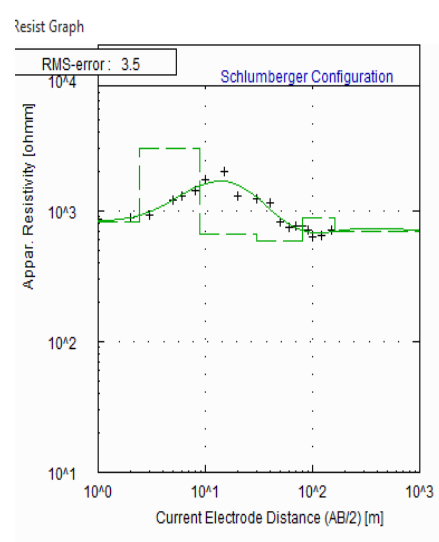

(c)

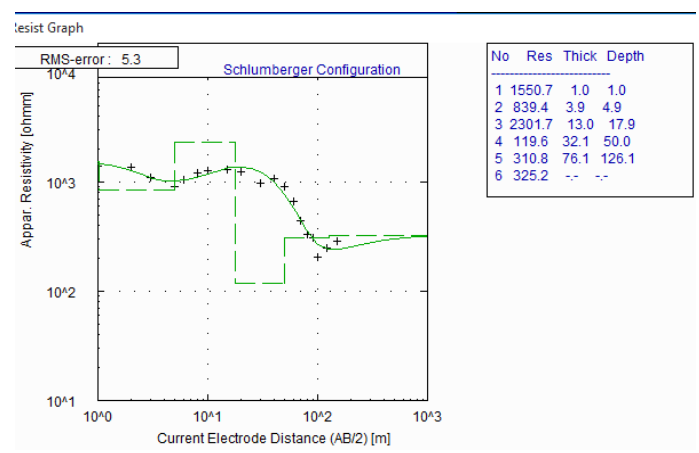

(b)$$
\text { lesist Grap }
$$

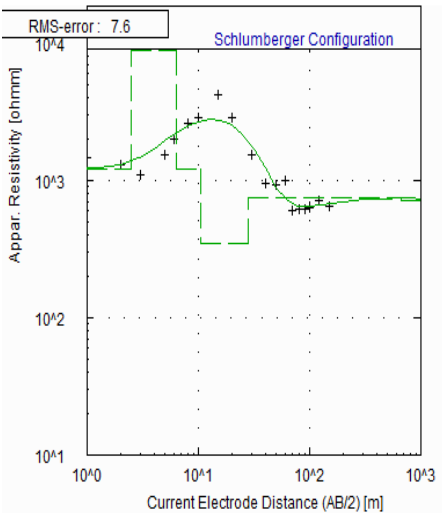

(d)

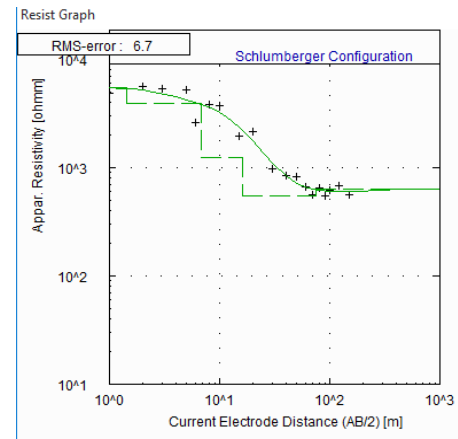

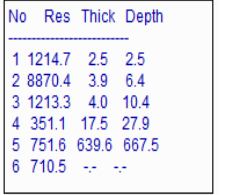

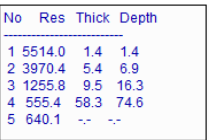

Fig. 2: Examples of the model curves from the VES data: a) VES 01; b) VES 02; c) VES 03 and d) VES 04

all points of maxima and minima are indicators of different lithologies. Similarly where the resistivity balues tends to infinity it is an indication of the fresh basement rock (Zohdy, 1989; Telford at., 1990).

Based on the partial curve matching, initial estimates of the resistivities and thickness of the various geoeletric layers were obtained. These were used as starting models for a computer based invasion procedure. The commercially available WinResist Software was used for the quantitative interpretation. The inversion procedure uses a least square approach (Zohdy, 1989; Loke and Barker, 1996 and Amidu and Dunbar, 2008) to minimize the difference between the input data and the theoretically derived curves. Due to handy controls, the WinResist was able to choose from a set of equivalent solutions the one that best fit both the geophysical and geological data.

VES curves: Figure 2 shows the model curves for some of the VES data. The sounding curves reflect possible presence of 3 geoelectric layers. The dominant curves are $\mathrm{KH}$-types, comprising of 5 out of the 7 interpreted VES curves and are found in various parts of the survey area. The detail interpreted resistivity values, layer thickness and layer depths are summarized in Table 1. The first layer in all cases is interpreted as the top soil with model. The thickness is variable and mostly $<2 \mathrm{~m}$. The middle weathered layer has a depth to the base of the layer $<30 \mathrm{~m}$. Underlying, the weathered layer are the fractured layers and fresh basement. Whereas the fractured layers have interpreted resistivity $>100 \mathrm{~m}$, the fresh basement mostly has interpreted resistivity $<1500 \mathrm{~m}$.

The top 2 layers correspond to the reddish brown top soil with over lying lateritic clay layer. The underlying geoelectric layer consists of the weathered profile which is clay rich and represents region of progressive chemical degredation from fresh basement rock to soil (Acworth, 1987; Amidu and Olayinka, 2006). The layer is thickest, around $30 \mathrm{~m}$ at the central part of study at VES 4. The deepest geoelectric layers observed are interpreted as hard basement rocks. This hard basement is infinite thickness and higher resistivities (Olayinka as., 2004). In some interpretations, however, the interpreted resistivities for the lowermost layers are found to be relatively low $(<1500 \mathrm{~m})$ for a fresh basement. In this case, the sounding is adjudged to have encountered the fractured basement where presence of water within the fracture contributes to the lower resistivity (Olayinka, 
Table 1: Results of computer modeling interpretation of the VES curves

\begin{tabular}{|c|c|c|c|c|}
\hline VES No./Layer No. & Thickness (m) & Resistivity $(\Omega)$ & Lithotype & Curve types \\
\hline \multicolumn{5}{|l|}{1} \\
\hline 1 & $0-2$ & 870 & Top soil & \multirow[t]{5}{*}{$\mathrm{AH}$} \\
\hline 2 & $2-6$ & 1300 & Lateritic clay & \\
\hline 3 & $6-30$ & 2000 & Weathered basement & \\
\hline 4 & $30-80$ & 760 & Fairly hard basement & \\
\hline 5 & $\geq 80$ & 700 & Hard basement & \\
\hline \multicolumn{5}{|c|}{ H } \\
\hline 1 & $0-2$ & 1450 & Top soil & \multirow[t]{5}{*}{$\mathrm{AH}$} \\
\hline 2 & $2-6$ & 1560 & Lateritic clay & \\
\hline 3 & $6-30$ & 2885 & Weathered basement & \\
\hline 4 & $30-60$ & 950 & Freshly weathered basement & \\
\hline 5 & $\geq 60$ & 620 & Hard basement & \\
\hline \multicolumn{5}{|c|}{ 20. } \\
\hline 1 & $0-1$ & 1400 & Top soil & \multirow[t]{6}{*}{$\mathrm{AH}$} \\
\hline 2 & $1-6$ & 1050 & Lateritic clay & \\
\hline 3 & $6-20$ & 1220 & Highly weathered basement & \\
\hline 4 & $20-50$ & 910 & Weathered basement & \\
\hline 5 & $50-80$ & 310 & Freshly weathered basement & \\
\hline 6 & $\geq 80$ & 250 & Hard basement & \\
\hline \multicolumn{5}{|c|}{ 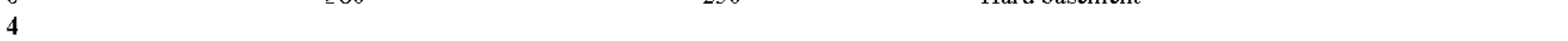 } \\
\hline 1 & $0-1$ & 4860 & Top soil & \multirow[t]{5}{*}{$\mathrm{AH}$} \\
\hline 2 & $1-6$ & 5350 & Lateritic clay & \\
\hline 3 & $6-20$ & 3500 & Weathered basement & \\
\hline 4 & $20-50$ & 850 & Freshly weathered basement & \\
\hline 5 & $50-80$ & 600 & Hard basement & \\
\hline \multicolumn{5}{|c|}{ 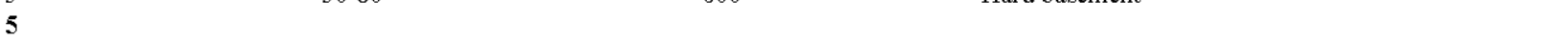 } \\
\hline 1 & $0-2$ & 750 & Top soil & \multirow[t]{5}{*}{$\mathrm{AH}$} \\
\hline 2 & $2-10$ & 620 & Lateritic clay & \\
\hline 3 & $10-40$ & 730 & Weathered basement & \\
\hline 4 & $40-70$ & 560 & Freshly weathered basement & \\
\hline 5 & $\geq 70$ & 710 & Fresh basement & \\
\hline \multicolumn{5}{|c|}{ 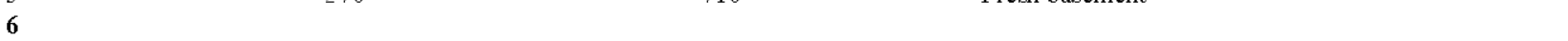 } \\
\hline 1 & 1.6 & 833.8 & Top soil & \multirow[t]{6}{*}{$\mathrm{AH}$} \\
\hline 2 & 8.4 & 510.1 & Lateritic clay & \\
\hline 3 & 19.1 & 170.1 & Weathered basement & \\
\hline 4 & 29.1 & 215.9 & Freshly weathered basement & \\
\hline 5 & 59.0 & 291.0 & Fractured basement & \\
\hline 6 & $\geq 117.2$ & 536.2 & Fresh basement & \\
\hline \multicolumn{5}{|l|}{7} \\
\hline 1 & 1.4 & 583.7 & Top soil & \multirow[t]{6}{*}{$\mathrm{AH}$} \\
\hline 2 & 8.0 & 508.6 & Lateritic clay & \\
\hline 3 & 18.0 & 227.6 & Weathered basement & \\
\hline 4 & 31.0 & 359.8 & Freshly weathered basement & \\
\hline 5 & 63.8 & 308.7 & Fractured basement & \\
\hline 6 & $\geq 122.2$ & 655.2 & Fresh basement & \\
\hline
\end{tabular}

1992). These fractured basements with exceptionally low resistivities are inferred to be saturated and are potential targets for groundwater supply (Olayinka a a., 2004; Oladunjoye eas., 2013).

The results of this study have helped to better understand subsurface geoelectric distribution, basement topography and the possible hydrogeology of the basement complex within Landmark University, Omu-Aran. The 3 and 4-layer model curves obtained from the VES interpretations together with resistivity values are consistent with results from previous VES surveys in other areas in the basement complex of Nigeria as reported in the literature (Ajayi and Adegoke-Anthony, 1988; Okhue and Olorunfemi, 1991 and Olayinka $\left.{ }_{\text {eal. }}, 2004\right)$. The curve types correlates with the report by Oladunjoye et as. (2013) who discovered the predominance 16 H-type curves at Awotan area of Ibadan, Southwestern, Nigeria. Olorunfemi a a. (1992), show that various complex combinations of $\mathrm{H}, \mathrm{A}$ and $\mathrm{K}$ curves, yielding multiple geoelectric layers are possible, especially for relatively deep fractured basement aquifers.

In this study generally, the sub surface layers comprise of the top lateritic soil, weathered layer, fractured basement and fresh basement. This is well aligned with results by Olayinka ea. (2004). The fractured and weathered basement with relatively lower resistivity is inferred to be the aquiferous zone and could bear productive water for groundwater supply (Oladunjoye ${ }_{\text {eal. }}$, 2013). The weathered layer constitute the hydro geologically significant layer because of its water 
bearing capacity and relatively high porosity, permeability and specific yield (Acworth, 1987) whereas fractures significantly influence the groundwater yield because of the higher permeability (Olorunfemi ${ }_{\text {as. }}, 1999$ ).

\section{CONCLUSION}

The VES survey has contribute greatly to the knowledge and understanding of the hydrogeology of the basement complex in the area. The subsurface layers are found to be comprised of the top lateritic soil, weathered layer, fractured basement and fresh basement. Potentially good resources for suitable drinkable water supply are basement aquifers. Areas with relatively high thickness of the weathered layer and with low resistivity values of the weathered and fracture zones have been successfully identified as potential targets for sinking boreholes.

\section{REFERENCES}

Abedi, M., A. Gholami and G.H. Norouzi, 2013. A stable downward continuation of airborne magnetic data: A case study for mineral prospectivity mapping in Central Iran. Comput. Geosci., 52: 269-280.

Acworth, R.I., 1987. The development of crystalline basement aquifers in a tropical environment. Q. J. Eng. Geol. Hydrogeol., 20: 265-272.

Ajayi, O. and C.W. Adegoke-Anthony, 1988. Groundwater prospects in the basement complex rocks of Southwestern Nigeria. J. Afr. Earth Sci. (Middle East), 7: 227-235.

Ajayi, T.R., 1981. On the geochemistry and origin of the amphibolites in ife-ilesha area SW Nigeria. J. Min. Geol., 17: 179-196.

Ako, B.D., 1980. A contribution to mineral exploration in the Precambrian belt of part of southwestern Nigeria. J. Min. Geol., 17: 129-138.

Amidu, S.A. and A.I. Olayinka, 2006. Environmental assessment of sewage disposal systems using 2D electrical-resistivity imaging and geochemical analysis: A case study from Ibadan, Southwestern Nigeria. Environ. Eng. Geosci., 12: 261-272.

Amidu, S.A. and J.A. Dunbar, 2008. An evaluation of the electrical-resistivity method for water-reservoir salinity studies. Geophysics, 73: G39-G49.

Annor, A.E., S.B. Olobaniyi and A. Mucke, 1997. Silicate facies iron-formation of the Egbe-Isanlu Palaeoproterozoic schist belt, southwest Nigeria. J. Afr. Earth Sci., 24: 39-50.

Loke, M.H. and R.D. Barker, 1996. Rapid least-squares inversion of apparent resistivity pseudosections by a quasi-Newton method. Geophys. Prospect., 44: 131-152.
Obaje, N.G., 2009. Geology and Mineral Resources of Nigeria. Springer, Berlin, Germany, ISBN-13: 9783540926849, Pages: 221.

Okhue, E.T. and M.O. Olorunfemi, 1991. Electrical resistivity investigation of a typical basement complex area. J. Mining Geol., 26: 243-250.

Olade, M.A. and A.A. Elueze, 1979. Petrochemistry of the Ilesha amphibolites and Precambrian crustal evolution in the Pan-African domain of SW Nigeria. Precambrian Res., 8: 303-318.

Oladunjoye, M.A., A.O. Akanji and O.T. Akingbesote, 2013. Groundwater exploration in alakuta-awotan area of ibadan, Southwestern Nigeria. J. Geol. Geosci., Vol. 2. 10.4172/2329-6755.1000124

Olasehinde, P.I., P.C. Pal and A.E. Annor, 1990. Aeromagnetic anomalies and structural Lineaments in the Nigerian basement complex. J. Afr. Earth Sci. Middle East, 11: 351-355.

Olayinka, A.I., 1992. Geophysical siting of boreholes in crystalline basement areas of Africa. J. Afr. Earth Sci. (Middle East), 14: 197-207.

Olayinka, A.I., S.A. Amidu and M.A. Oladunioye, 2004. Use of electromagnetic profiling and resistivity sounding for groundwater exploration in the crystalline basement area of Igbeti, Southwestern Nigeria. Global J. Geol. Sci., 2: 243-253.

Olorunfemi, M.O., J.S. Ojo and O.M. Akintunde, 1999. Hydro-geophysical evaluation of the groundwater potentials of the Akure metropolis, Southwestern Nigeria. J. Mining Geol., 35: 207-228.

Oyinloye, A.O., 1998. Geology, geochemistry and origin of the banded gneisess in the basement complex of Ilesha area South Western Nigeria. J. Adrican Earth Sci., 26: 633-641.

Rahaman, M.A., 1988. Recent Advances in the Study of the Basement Complex of Nigeria. In: Precambrian Geology of Nigeria, Geological Survey of Nigeria, (Ed.). Geological Survey of Nigeria, Kaduna South, Nigeria, ISBN: 9789783018709 , pp: 11-43.

Scheidegger, A.E. and D.E. Ajakaiye, 1985. Geodynamics of Nigerian shield areas. J. Afr. Earth Sci., 3: 461-470.

Telford, W.M., L.P. Geldart and R.E. Sheriff, 1990. Applied Geophysics. 2nd Edn., Cambridge University Press, Cambridge, UK., ISBN:9780521326933, Pages: 770 .

Woakes, M., M.A. Rahaman and A.C. Ajibade, 1987. Some metallogenetic features of the Nigerian basement. J. Afr. Earth Sci., 6: 655-664.

Zohdy, A.A.R., 1989. A new method for the automatic interpretation of Schlumberger and Wenner sounding curves. Geophysics, 54: 245-253. 